\title{
Response to the Symposium Panel
}

\author{
Kennan Ferguson
}

$\mid$ am thankful for such a rich and engaged set of responses. Or, at least, half-thankful: one of the preeminent values of any symposium emerges from the conceptual divergences between the claims of the original essay and those of the respondents, and here (I fear) all of us are in such basic agreement as to risk a mere rehash of the primary points. We all concur, so far as I can tell, that political science in the United States desperately needs more Native presence: epistemologically, historically, conceptually, and literally. Each of us finds reasons for optimism, but our hopes are tempered by a recognition of the built-in biases of the discipline, ones reinforced by tradition, structure, and temperament.

So the usual focus of a summary essay in a symposiumthe aggrieved defense of an original thesis against the tide of criticism marshalled by eminent scholars-doesn't really apply here. Instead, this portion of the symposium can emphasize and reinforce the useful addenda that the commentators provide. One primary contribution many make is toward the development of a set of bibliographic resources available to scholars of indigenous North America. Taken together, the works outlined in the endnotes to these responses prove an impressive corrective to my original contention that "very few Native issues" are considered important within political science. A second major contribution is the focus of both Carpenter and Frymer on the subfield of American Political Development, a locale where work on settler colonialism can and has been done with excellent results. My own background in political theory occluded my knowledge of much of this scholarship, a clearly emergent major research area. A third contribution is merely the presence of the scholars themselves: here are six notable political scientists willing and able to generously dedicate their time and work in the directions we all agree are vital.

Perhaps the only area of substantive disagreement I have with the respondents is with a point made in different ways by MacLean, Wilmer, and Proudfit: that

Kennan Ferguson teaches political theory at the University of Wisconsin-Milwaukee, where he also directs the Center for 21st Century Studies (kennan@uwm.edu). many smart, driven, and even academically-minded Native students are drawn away from the abstractions of academia into more rooted and activist community needs such as social work, law, children's education, or health care. This is partially true-many of the most dedicated Native high school students and undergraduates want very strongly to serve their own people in immediate ways. I know of one Native student who, upon receiving his Ph.D. in political science from the University of Colorado, turned down a tenure-track position in the continental United States in favor of an equally challenging, but more community-embedded, non-academic position.

But a quick comparison with many other disciplines belies at least part of this claim. There are a considerable number of Native professors of literature, or of history, or of museum studies. They clearly do not hold a numerically representative share of those academic professions, but they have a notable presence. These disciplines do not hold more immediate application than politics; they certainly have no more "importance" than the study of law, treaties, and power. Yet they provide a conceptual and intellectual home to Native epistemologies and research in ways that political science does not.

Other evidence against the "immediacy" presumption comes from the pedagogical experience of another of the respondents. I have met a number of Native scholars who sought out Wilkins precisely to study politics with him: they speak highly of his demanding attention to the intricacies of legal theory and treaty obligations, and their subsequent publication records demonstrate their scholarly dedication. But when they went on the academic job market, none (that I know) found a home in political science in the United States. They were hired instead by Canadian political science departments, or in Native American Studies programs or departments in the Unites States.

In other words, even though the supply may be small, the demand is even smaller. And all of us-myself and each respondent-find this both intellectually limiting and morally problematic. I do agree with Proudfit that many Native students engage in "actualizing political science." But this should make our own discipline more - not less-attentive to the issues and communities to which they commit themselves.

doi:10.1017/S1537592716002978 
Time could be spent on smaller disagreements. Wilmer notes the excellent volume Political Theory and the Rights of Indigenous Peoples, but implies it includes indigenous U.S. authors who are within political science; unless I am incorrect, the only U.S. Native in the collection is the anthropologist Audra Simpson. Nor am I convinced by Frymer's disaggregation of "methodological fetishism" from "ideological imposition"; I would argue, in contrast, that a critical analysis of the past century of political science would show a disturbing correlation between racial formation, state power, economic liberalization, and colonialism of both the settler and the imperial varieties.

But put those aside in the interest of combating the structural forces which make political science hate American Indians. How can we take on Wilkins's fact that "those who have power and influence in our field have no incentive to question, let alone change, the existing paradigm"? Clearly, an individualized approach is insufficient; those who wish to indigenize political science constitute small voices in big departments and an even bigger field. So let us think beyond what each political scientist can do in his or her own work, finding suggestive possibilities together. Perhaps expanding the conceptual frameworks of our discipline beyond our current, limited definitions of power. Perhaps developing coalitions with Native students (both undergraduate and graduate), who have long been fighting against the academic structures that exclude them. Perhaps challenging what MacLean terms the "dominant epistemological assumptions" when they first appear in our students' and colleagues' research. And perhaps directing ignominy at places susceptible to political pressure: large departments hiring a second professor of state politics who structure their job advertisements to exclude scholars of regional Native issues, for example. If the exclusions of Native voice, concepts, epistemologies, and people are truly structural, it will take structural criticism and irruption to overcome them. The study of politics demands more; we should demand more, too. 